\title{
INFLUENCE OF POSITIVE AND NEGATIVE FACTORS ON THE UNIVERSITY STUDENTS' HEALTH
}

DOI: 10.36740/WLek202008128

\author{
Grygoriy P. Griban' ', Zoia M. Dikhtiarenko², Eduard A. Yeromenko², Andrii M. Lytvynenko ${ }^{3}$, Alla A. Koval2, \\ Irina V. Ramsey ${ }^{4}$, Vadym 0. Muzhychok ${ }^{5}$ \\ 'ZHYTOMYR IVAN FRANKO STATE UNIVERSITY, ZHYTOMYR, UKRAINE \\ ¿UNIVERSITY OF STATE FISCAL SERVICE OF UKRAINE, IRPIN, UKRAINE \\ ${ }^{3}$ KHARKIV NATIONAL UNIVERSITY OF RADIO ELECTRONICS, KHARKIV, UKRAINE \\ ${ }^{4}$ MUNICIPAL ESTABLISHMENT “KHARKIV HUMANITARIAN PEDAGOGICAL ACADEMY" OF KHARKIV REGIONAL COUNCIL, KHARKIV, UKRAINE \\ ${ }^{5}$ VINNYTSIA MYKHAILO KOTSIUBYNSKYI STATE PEDAGOGICAL UNIVERSITY, VINNYTSIA, UKRAINE
}

\begin{abstract}
The aim is to analyze the factors that affect the students' health both positively and negatively and to evaluate the real health status of Ukrainian student youth.

Materials and methods: The research was conducted at Zhytomyr Ivan Franko State University and University of State Fiscal Service of Ukraine, 647 students of the 1st - 4th years of study were examined. To study both negative and positive factors, we conducted a survey of the students of different genders of several education departments, using original questionnaires. To analyze the results of the students' self-assessment of their health state, the methodology of V. P. Voitenko, which contains 27 questions that characterize the most important aspects of well-being, mood, activity, sleep quality, pain senses and lifestyle of students, was applied.

Results: It was determined that the most important factors for the preservation of health included nutrition, physical activity, active leisure, sleep, love and sex. $56.3 \%$ of male students and $49.9 \%$ of female ones indicated that motor activity is of great importance for health care. The students stated that the most dangerous health factors included drug use, radioactive contamination of the environment, smoking, alcohol abuse, stress, etc. It was found that the highest percentage of students had satisfactory and poor health levels $-44.8-54.9 \%$ and $17.8-29.5 \%$ respectively.

Conclusions: A wide range of specific components of the educational process and the healthy lifestyle of students can have different effects on life. Lifestyle is one of the many factors that affect students' health. The students' self-assessment of their health state lets to manage the educational process of physical education efficiently, allocate physical activity and apply individual tasks rationally.
\end{abstract}

KEY WORDS: health, factors, physical education, students

Wiad Lek. 2020;73(8):1735-1746

\section{INTRODUCTION}

Health and fitness activity at higher educational institutions (HEI) of Ukraine is considered to be the basis of the professional health and physical capacity of future specialists, who must be competitive in the modern European labor market $[1,2,3]$. Despite some efforts to improve the higher educational system in Ukraine, a negative trend of the deterioration of the health and physical fitness of students remains. However, it is known that human health is mainly formed by the following four factors: human genetics and biology, environment, lifestyle and health care $[4,5,6]$. Therefore, the problem of health remains one of the most pressing problems both at the level of scientific knowledge and at the level of everyday consciousness.

The scientists $[7,8]$ consider "health" to be a state of an organism that enables a person to implement one's genetic program to the fullest extent in the specific conditions of socio-cultural existence. From these perspectives, health should be considered as a concept of the dynamic state depending on three aspects: individual, age, historical. G. L. Apanasenko [9], R. S. Paffenbarger, E. Olsen [10] consider health as one of the main conditions of human happiness, which is the state of complete physical, mental, sexual and social well-being, the ability to adapt to the conditions of the external and internal environment, which are constantly changing according to the natural process of aging, as well as the absence of diseases and physical defects. Working on the development of the health doctrine, E. Gh. Bulych, Y. V. Muravov [4] state that there are more than 300 definitions of health. The critical evaluation of a large number of definitions of health indicates that this concept is multifaceted and it has different interpretations, which should be specified.

In 1948, World Health Organization gave the following definition: "Health is a state of complete physical, mental and social well-being but not just the absence of diseases or physical disabilities" [11]. No clarifications or changes have been made to this definition so far. Despite various new definitions and proposals, World Health Organization's definition of health remains an important reference to what constitutes human health. The research of M. Ya. Vilenskiy [12] shows that out of the total number of factors that in- 
fluence the formation of students' health (taken as 100\%), physical education accounts for 15-30\%, sleep - for 24-30 $\%$, nutrition - for 10-16\%, and the total effect of other factors - for 24-50\%. The study of O. Gninyuk [13] of the subjective health state of engineering students showed that their health status consisted of five factors, contributing $83.1 \%$. This made it possible to determine the content of the control over the state of health of the specified contingent: 1) the factor of "general condition after sleep" (23.7 $\%)$ makes the most important contribution; 2) "energy potential" $(21.1 \%)$ is the indicator of a desire to move; 3 ) "fatigue" (14.2\%) - fatigue after activities; 4) "organism recovery" (13.4\%) - the quality of sleep; 5) "metabolism" $(10.7 \%)$ - sweating. However, this information applies only to the contingent of the study. The formation of appropriate structures in students of different ages, genders, professions, and places of residence may occur with changes in the informational significance of indicators and contributions of certain factors.

O. Malimon, A. Volchinskiy [14] distributed the factors that shape human health in the following way: lifestyle - 49-53\%, environment - 17-20\%, heredity - 18-22\%, health care system $-8-10 \%$. The scientists $[15,16]$ put lifestyle factors, which include the level and quality of life (financial security parameters), lifestyle (psychological, individual behavior peculiarities), the scheme of life (national, social, everyday life, culture), negative lifestyle factors (smoking, alcohol abuse, drug use, poor nutrition, stress, hypodynamia, harmful working conditions, etc.) to the first place (51-52\%). The biological factors (gender, age, heredity, constitution) were rated the second (20-21 $\%$ ), environmental factors (the state of air, water, food, soil, the level of radioactive contamination) - the third (19-21 $\%)$. In literary sources $[17,18,19,20,21]$, there are dozens of different distributions of the factors that affect human health, but they are not significantly different.

Human behavior has the most powerful impact on health. No element of the regulation of resiliency and health self-assessment remains inactive under the influence of behavior [22]. Human behavior generates emotions that affect the metabolism and energy metabolism in the most concentrated form, which provides nonspecific (from the physical environment) and specific (from social conditions) information gain. All of these influences fundamentally alter the objective basis of health - resiliency [23]. Forming various functional states of an organism, human behavior, and activity change the potential of human health dramatically. In a large set of behavior influences, there are three main factors that have an extremely important impact on resiliency: 1) social - an interaction between people, which forms a variety of health-improving and opposite effects; 2 ) the person's inner attitudes that produce different effects on health; 3) motor activity that is able to significantly develop and enhance the potential for human health. Each of these factors affects a person mostly not separately but in combination with other factors. Their interaction is manifested in the student environment most significantly in the process of study, rest, exercise and sports [24, 25].

\section{THE AIM}

The aim of the study is to analyze the factors that affect the students' health both positively and negatively and to evaluate the real health status of Ukrainian student youth. The objectives:

1) to study the factors that influence the students' health; 2) to analyze the students' self-assessment of their health.

\section{MATERIALS AND METHODS}

The research was conducted at Zhytomyr Ivan Franko State University and University of State Fiscal Service of Ukraine, 647 students of the 1st - 4th years of study were examined. To study both positive and negative factors, we conducted a survey of the students of different genders of several education departments, using original questionnaires. To analyze the results of the students' self-assessment of their health state, the methodology of V. P. Voytenko [26], which contains 27 questions that characterize the most important aspects of well-being, mood, activity, sleep quality, pain senses and lifestyle of students, was applied. The first 26 questions are the ones with a "yes" or a "no" answer, and the last question includes the next options: "good", "satisfactory", "poor", "very poor". A respondent receives 1 point for each "yes" answer and 0 points - for the answer "no". The final score gives a quantitative self-assessment of health. Accordingly, if the answer to the last question is "bad" or "very bad", 1 point is added. A student's level of health was rated as perfect if one received $0-3$ points, good - 4-7 points, satisfactory $-8-13$ points, poor $-14-20$ points, very poor $-21-27$ points.

To conduct the study, we chose standard and modern methods, including the analysis and generalization of scientific and methodological literature, the analysis of the results of students ' activity and generalization of the experience of advanced pedagogical practice, questionnaire, pedagogical observation and conversations with teachers and students, the methods of mathematical statistics.

This study complies with the ethical standards of the Act of Ukraine "On Higher Education" No. 1556-VII dated 01.07.2014 and the Letter from the Ministry of Education and Science of Ukraine "On the Academic Plagiarism Prevention" No. 1/11-8681 dated 15.08.2018. Also, this study followed the regulations of the World Medical Association Declaration of Helsinki - ethical principles for medical research involving human subjects. Informed consent was received from all individuals who took part in this research.

\section{RESULTS}

To solve the first task of the study, we conducted surveys of the students of different genders, years of study and education departments, applying original questionnaires, meeting all the requirements for sociological research. It was found that the students defined the next factors that are the most important for health preservation: nutrition, physical activity, active leisure, sleep, love and sex, phytotherapy (Table I). Motor activity is most highly rated by 
Table I. The results of the evaluation of the factors that have a positive impact on health by the students of different years of study ( $n=647, \%$ )

\begin{tabular}{|c|c|c|c|c|c|c|}
\hline \multirow{2}{*}{ Factors } & \multirow{2}{*}{ Gender } & \multicolumn{4}{|c|}{ Years of study } & \multirow{2}{*}{$\begin{array}{c}\text { Total } \\
\% \\
\end{array}$} \\
\hline & & $1 \mathrm{st}$ & 2nd & $3 r d$ & 4th & \\
\hline \multirow{2}{*}{ Nutrition } & males & 62.9 & 62.5 & 71.4 & 64.7 & 64.3 \\
\hline & females & 56.1 & 49.2 & 60.8 & 57.6 & 53.8 \\
\hline \multirow{2}{*}{ Physical activity } & males & 53.3 & 59.4 & 65.7 & 50.0 & 56.3 \\
\hline & females & 35.4 & 56.5 & 60.8 & 42.4 & 49.9 \\
\hline \multirow{2}{*}{ Active leisure } & males & 41.9 & 43.8 & 45.7 & 50.0 & 44.1 \\
\hline & females & 62.2 & 55.0 & 45.1 & 61.2 & 56.5 \\
\hline \multirow{2}{*}{ Sleep } & males & 40.0 & 54.7 & 31.4 & 58.8 & 45.4 \\
\hline & females & 59.6 & 48.2 & 51.0 & 58.8 & 53.1 \\
\hline \multirow{2}{*}{ Love and sex } & males & 43.8 & 56.3 & 57.1 & 44.4 & 49.2 \\
\hline & females & 34.1 & 30.4 & 31.4 & 34.1 & 32.0 \\
\hline \multirow{2}{*}{ Phytotherapy } & males & 3.8 & 3.1 & 2.9 & 11.8 & 4.6 \\
\hline & females & 2.4 & 7.9 & 7.8 & 11.8 & 7.6 \\
\hline
\end{tabular}

Table II. The results of the evaluation of the factors that have a positive impact on health by the students of different educational departments $(\mathrm{n}=647, \%)$

\begin{tabular}{|c|c|c|c|c|}
\hline \multirow{2}{*}{ Factors } & \multirow{2}{*}{ Gender } & \multicolumn{3}{|c|}{ Educational departments } \\
\hline & & Special & Main & Sports \\
\hline \multirow{2}{*}{ Nutrition } & males & 69.8 & 61.9 & 64.4 \\
\hline & females & 41.2 & 57.9 & 56.9 \\
\hline \multirow{2}{*}{ Physical activity } & males & 52.8 & 54.8 & 62.7 \\
\hline & females & 48.5 & 50.2 & 50.8 \\
\hline \multirow{2}{*}{ Sleep } & males & 54.7 & 42.1 & 44.1 \\
\hline & females & 39.2 & 52.6 & 63.1 \\
\hline \multirow{2}{*}{ Active leisure } & males & 50.9 & 43.7 & 39.0 \\
\hline & females & 55.7 & 57.1 & 55.4 \\
\hline \multirow{2}{*}{ Love and sex } & males & 54.7 & 46.8 & 49.2 \\
\hline & females & 39.2 & 32.8 & 18.5 \\
\hline \multirow{2}{*}{ Phytotherapy } & males & 11.3 & 3.2 & 1.7 \\
\hline & females & 11.3 & 7.3 & 3.1 \\
\hline
\end{tabular}

the students of the 2 nd and 3 rd years. In general, the role of motor activity in health preservation was estimated not very high by students, as indicated by $56.3 \%$ of male students and $49.9 \%$ of female students.

The analysis of the evaluation of the factors that have a positive impact on the health of students from different educational departments showed some differences. Thus, the students of the sports educational department gave greater preference to nutrition, physical activity, sleep, and less preference for active leisure, love and sex, and phytotherapy. The students of the main and special educational departments gave greater preference to nutrition, physical activity, active leisure, and less preference to sleep (Table II).

Among the most dangerous factors for health, the students distinguished drug use, radioactive contamination of the environment, smoking, alcohol abuse, heavy metals in food, pesticides, nitrates, nervous conflicts, negative psychological climate, stress, and others (Table III). The majority of students of both genders ranked drug use as the biggest negative factor for health. Only the fourth-year male students put radioactive contamination in the first place. The male and female students of different years had dissimilar approaches to the evaluation of other dangerous factors. Physical inactivity was ranked the 8 th by males and the 9th by females, as evidenced by physical education classes and health and fitness activities. Heredity was ranked the last among the identified negative factors.

The views on forming the rating of dangerous factors for human health of the students of different educational departments differed. The drug use was rated the first in all educational departments. But the students of different gender and different years of study have slightly different opinions concerning other factors (smoking, radioactive contamination, alcohol abuse, etc.) (Table IV).

An important factor that positively affects students' health is motor activity. The realization of this factor is carried out through the educational process in physical education at HEI. The criterion of the efficiency and quality of the educational process in physical education is the student's manners, that is, the presence of high spiritual qualities, which are based on an internal desire to systematically maintain the state of health, a sufficient level of physical fitness and development, love for physical culture and sports, and in general, following a healthy lifestyle.

There are many factors that encourage students to do physical exercises and sports, but they lose their power 
quite often when students face some difficulties and obstacles. The main factors contributing to the positive attitude of students to physical education are responsibility and discipline, which was defined to be characteristic only for $30.9 \%$ of students. Only $27.9 \%$ of students wanted to enjoy attending classes, $21.9 \%$ had a positive attitude due to the physical education teacher's educational work, 10.8 $\%$ followed the example of friends, and $3.2 \%$ followed the example of parents (Table V). A very small number of students $(16.8 \%)$ strove for harmonious spiritual and physical development. The control of the dean's office and the department of physical education was also indicated as an important factor.

The main factor contributing to the positive attitude of the students of sports educational departments to physical education was enjoying exercises ( $46.0 \%)$, as well as responsibility and discipline (37.9\%). It should also be mentioned that a very low motivating factor for exercising for many students was an example of parents and their requirements (Table VI). In spite of the low level of physical development and physical fitness and health defects, the dominant factors of the positive attitude to the educational activities of the students of the special educational department were responsibility and discipline, the control of a physical education teacher, the department and the dean's office.

The studies also confirmed that there were students (2.5 $\%$ of males and $3.9 \%$ of females) who were not sure that physical exercises and sports have a positive effect on their health. A large number of students $(20.6 \%$ of males and $30.6 \%$ of females) were not quite sure about the positive role of exercise (Table VII). It was caused, on the one hand, by a lack of awareness of the motor activity impact on the health state, physiological and psychological processes; on the other hand, by the violations of the exercises techniques and dosing of physical activity by teachers and students, which could lead to overloads, illnesses, injuries, accidents, negative emotional states, etc.

At the same time, even more striking results were obtained from the students of the sports department, where $3.4 \%$ of males and $6.2 \%$ of females believed that sports have a negative effect on their health (Table VIII). This group included students who had achieved high athletic performance in certain sports, which had required excessive physical activity, maintaining proper body weight, a strict diet, and generally limited life. Another reason was also students' dissatisfaction with their sports achievements, uncertainty in the future life, i.e. frustration, the loss of a purpose. The female students of the special educational department (5.2\%) indicated that the main reason for the poor evaluation of physical exercises was the replacement of health-improving properties of physical exercises with their therapeutic features for certain diseases.

Unfortunately, $34.9 \%$ of male students and $40.4 \%$ of female ones did not attend additional classes or conducted extracurricular classes. Only $15.1 \%$ of males and $8.1 \%$ of females systematically maintain their physical fitness. Only $34.2 \%$ of students did exercises 1-2 times a week independently, and $16.8 \%-2-3$ times (Table IX).
The most significant factors contributing to the formation of students' positive attitude to attending and conducting independent physical exercises and sports classes were indicated to be the desire to improve health (56.1\%), to be attractive (36.5\%), to enjoy doing physical exercises and sports (25.3\%), a positive example of a physical education teacher $(21.5 \%)$, a harmonious combination of the spiritual state with physical development $(20.1 \%)$, the desire to improve sports performance (19.8\%), friends (19.5\%) and others (Table X). Parents, statesmen and politicians, well-known athletes, sporting events and the requirements for professional activity have a small influence on the involvement of students in systematic independent exercise. It should also be noted that there is a lack of advocacy among school and university students and through the media and television, and society does not properly value a "health" specialist.

It should also be mentioned that the health and well-being of students is affected by the mood in which students are for a long time. According to the research by B. Semeniv, A. Babych, P. Bilenjkyj et al. [27], fun, optimistic people with a sense of well-being and happiness not only feel healthier but they are healthier indeed. According to O. Zavydivska, N. Zavydivska, O. Khanikiants [28], such a statement is realistic and effective because subjective assessment of health and sense of well-being are more closely interrelated than objective health and well-being. V. P. Voytenko [26] indicates a significant relationship between subjective health self-evaluation and many objective indicators of the organism state. During questioning by the method of V. P. Voytenko, we found out how the students of the 1st -4 th years evaluate their own health (Table XI). It was defined that the highest percentage of students had satisfactory and poor health levels - 44.8-54.9\% and 17.8-29.5\% respectively. 18.1$21.9 \%$ of males and $14.7-19.9 \%$ of females had good level of health; 2.9-6.3 \% of males and 4.7-5.8 \% of males - very poor; only $1.9-3.1 \%$ of male students and 2.0-4.7 $\%$ of males - perfect. It should be noted that there were no significant differences between males and females in their health assessment status. The studies showed that unfortunately, students' health was not improved during their study at HEI. The obtained data are confirmed by the conclusions of other scientists [29, 30].

The students' health-evaluation depending on the education departments showed significant differences in a health state between the groups. For example, no students with perfect health were found in the special department. Only $1.9 \%$ of males and $2.1 \%$ of females had good health. $22.6 \%$ of males and $28.9 \%$ of females had a satisfactory level of health. It is of concern that $54.7 \%$ of males and $50.5 \%$ of females in the special educational department had poor health, and $20.8 \%$ and $18.5 \%$ respectively - very poor (Table XII). In the main educational department, the results were significantly better: $4.8 \%$ of male and 2.7 $\%$ of female students had perfect health, $19.1 \%$ and 21.5 $\%$ - good, $64.2 \%$ and $63.5 \%$ - satisfactory, $8.7 \%$ and 7.8 $\%$ - poor, $3.2 \%$ and $4.5 \%$ - very bad respectively. In the 
Table III. The results of the evaluation of the factors that negatively affect health by the students of different years of study ( $\mathrm{n}=647$, rank)

\begin{tabular}{|c|c|c|c|c|c|c|}
\hline \multirow{2}{*}{ Factors } & \multirow{2}{*}{ Gender } & \multicolumn{4}{|c|}{ Years of study } & \multirow{2}{*}{ Overall rating } \\
\hline & & $1 \mathrm{st}$ & 2nd & 3rd & 4th & \\
\hline \multirow{2}{*}{ Drug use } & males & 1 & 1 & 1 & 2 & 1 \\
\hline & females & 1 & 1 & 1 & 1 & 1 \\
\hline \multirow{2}{*}{ Radioactive contamination } & males & 3 & 3 & 2 & 1 & 2 \\
\hline & females & 4 & 3 & 4 & 3 & 3 \\
\hline \multirow{2}{*}{ Smoking } & males & 2 & 2 & 3 & 4 & 3 \\
\hline & females & 2 & 4 & 2 & 4 & 2 \\
\hline \multirow{2}{*}{ Alcohol abuse } & males & 5 & 4 & 4 & 5 & 4 \\
\hline & females & 3 & 2 & 3 & 2 & 4 \\
\hline \multirow{2}{*}{ Pesticides, nitrates, metals in food } & males & 4 & 5 & 5 & 3 & 5 \\
\hline & females & 6 & 5 & 6 & 6 & 6 \\
\hline \multirow{2}{*}{$\begin{array}{l}\text { Nervous conflicts, negative psychological } \\
\text { climate, stress }\end{array}$} & males & 6 & 7 & 7 & 6 & 7 \\
\hline & females & 5 & 6 & 5 & 5 & 5 \\
\hline \multirow{2}{*}{ Improper, inadequate and poor nutrition } & males & 7 & 6 & 6 & 7 & 6 \\
\hline & females & 7 & 7 & 7 & 7 & 7 \\
\hline \multirow{2}{*}{ Hypodynamia } & males & 8 & 8 & 8 & 8 & 8 \\
\hline & females & 9 & 9 & 8 & 9 & 9 \\
\hline \multirow{2}{*}{$\begin{array}{c}\text { Negative sanitary, hygienic and living } \\
\text { conditions }\end{array}$} & males & 9 & 9 & 9 & 9 & 9 \\
\hline & females & 8 & 8 & 9 & 8 & 8 \\
\hline \multirow{2}{*}{ Bad inherited characters } & males & 10 & 10 & 10 & 10 & 10 \\
\hline & females & 10 & 10 & 10 & 10 & 10 \\
\hline
\end{tabular}

Table IV. The results of the evaluation of the factors that negatively affect health by the students of different educational departments ( $n=647$, rank)

\begin{tabular}{|c|c|c|c|c|}
\hline \multirow{2}{*}{ Factors } & \multirow{2}{*}{ Gender } & \multicolumn{3}{|c|}{ Education departments } \\
\hline & & Special & Main & Sports \\
\hline \multirow{2}{*}{ Drug use } & males & 1 & 1 & 1 \\
\hline & females & 1 & 1 & 1 \\
\hline \multirow{2}{*}{ Smoking } & males & 4 & 2 & 3 \\
\hline & females & 3 & 3 & 2 \\
\hline \multirow{2}{*}{ Radioactive contamination } & males & 2 & 3 & 2 \\
\hline & females & 2 & 4 & 4 \\
\hline \multirow{2}{*}{ Alcohol abuse } & males & 5 & 4 & 4 \\
\hline & females & 4 & 2 & 3 \\
\hline \multirow{2}{*}{ Pesticides, nitrates, metals in food } & males & 8 & 6 & 6 \\
\hline & females & 6 & 5 & 5 \\
\hline \multirow{2}{*}{ Nervous conflicts, negative psychological climate, stress } & males & 3 & 5 & 5 \\
\hline & females & 5 & 6 & 6 \\
\hline \multirow{2}{*}{ Improper, inadequate and poor nutrition } & males & 6 & 7 & 7 \\
\hline & females & 7 & 7 & 7 \\
\hline \multirow{2}{*}{ Hypodynamia } & males & 7 & 8 & 8 \\
\hline & females & 9 & 9 & 8 \\
\hline \multirow{2}{*}{ Negative sanitary, hygienic and living conditions } & males & 9 & 9 & 9 \\
\hline & females & 8 & 8 & 9 \\
\hline \multirow{2}{*}{ Bad inherited characters } & males & 10 & 10 & 10 \\
\hline & females & 10 & 10 & 10 \\
\hline
\end{tabular}

sports educational department, $32.2 \%$ of males and $20.1 \%$ of females had a perfect health state, $49.2 \%$ of males and $32.1 \%$ of females - good, $18.6 \%$ and $46.2 \%$ - satisfactory respectively. The number of female students, who had poor health, accounted for $1.6 \%$ in the sports educational department. The results showed that the health state of males in the sports educational department was slightly better than that of females.

Conducting students' health assessments allowed us to obtain digital data that did not meet the age characteristics 
Table V. The factors contributing to the positive students' attitude to physical education classes ( $n=647, \%)$

\begin{tabular}{|c|c|c|c|c|}
\hline \multirow{2}{*}{ Factors } & \multirow{2}{*}{ Gender } & \multicolumn{2}{|c|}{ Years of study } & \multirow{2}{*}{$\begin{array}{c}\text { Total } \\
\%\end{array}$} \\
\hline & & $1 \mathrm{st}$ & 2nd & \\
\hline \multirow{3}{*}{ Responsibility and discipline } & male & 43.8 & 34.4 & 39.9 \\
\hline & female & 13.4 & 36.6 & 25.6 \\
\hline & overall & 30.5 & 36.0 & 30.9 \\
\hline \multirow{3}{*}{ Taking pleasure in physical exercises } & male & 25.7 & 40.6 & 31.1 \\
\hline & female & 18.3 & 29.3 & 26.2 \\
\hline & overall & 22.5 & 32.1 & 27.9 \\
\hline \multirow{3}{*}{ Physical education teacher } & male & 14.3 & 10.9 & 14.7 \\
\hline & female & 28.0 & 25.6 & 26.2 \\
\hline & overall & 20.3 & 21.9 & 21.9 \\
\hline \multirow{3}{*}{ Harmony of spiritual and physical development } & male & 16.2 & 25.0 & 18.9 \\
\hline & female & 14.6 & 14.1 & 15.6 \\
\hline & overall & 15.5 & 16.8 & 16.8 \\
\hline \multirow{3}{*}{$\begin{array}{l}\text { The control of the dean's office and the department } \\
\text { of physical education }\end{array}$} & male & 11.4 & 4.7 & 10.5 \\
\hline & female & 17.1 & 16.7 & 18.6 \\
\hline & overall & 13.9 & 13.7 & 15.6 \\
\hline \multirow{3}{*}{ The availability and accessibility of sports facilities } & male & 15.2 & 15.6 & 16.3 \\
\hline & female & 6.1 & 9.9 & 8.1 \\
\hline & overall & 11.2 & 11.3 & 11.1 \\
\hline \multirow{3}{*}{ Friends } & male & 10.5 & 21.8 & 13.0 \\
\hline & female & 7.3 & 12.0 & 9.5 \\
\hline & overall & 9.1 & 14.5 & 10.8 \\
\hline \multirow{3}{*}{ Parents } & male & 3.8 & 6.2 & 4.2 \\
\hline & female & 3.7 & 3.1 & 2.7 \\
\hline & overall & 3.8 & 3.9 & 3.2 \\
\hline
\end{tabular}

Table VI. The factors contributing to the positive attitude of the students of different educational departments to physical education classes $(n=647, \%)$

\begin{tabular}{|c|c|c|c|c|}
\hline \multirow{2}{*}{ Factors } & \multirow{2}{*}{ Gender } & \multicolumn{3}{|c|}{ Education departments } \\
\hline & & special & main & sports \\
\hline \multirow{3}{*}{ Taking pleasure in physical exercises } & male & 18.8 & 29.3 & 45.8 \\
\hline & female & 19.6 & 23.5 & 46.1 \\
\hline & overall & 19.3 & 25.5 & 46.0 \\
\hline \multirow{3}{*}{ Responsibility and discipline } & male & 32.1 & 42.8 & 40.6 \\
\hline & female & 28.7 & 21.8 & 35.4 \\
\hline & overall & 30.0 & 28.9 & 37.9 \\
\hline \multirow{3}{*}{$\begin{array}{l}\text { Harmony of spiritual and physical } \\
\text { development }\end{array}$} & male & 20.7 & 17.4 & 20.3 \\
\hline & female & 16.4 & 15.8 & 13.8 \\
\hline & overall & 18.0 & 16.4 & 16.9 \\
\hline \multirow{3}{*}{ Physical education teacher } & male & 28.3 & 10.3 & 11.9 \\
\hline & female & 22.6 & 29.5 & 18.5 \\
\hline & overall & 24.6 & 23.1 & 15.3 \\
\hline \multirow{3}{*}{ Friends } & male & 17.0 & 10.3 & 15.3 \\
\hline & female & 11.3 & 8.5 & 10.8 \\
\hline & overall & 13.3 & 9.1 & 12.9 \\
\hline \multirow{3}{*}{$\begin{array}{l}\text { The availability and accessibility of sports } \\
\text { facilities }\end{array}$} & male & 17.0 & 18.2 & 11.9 \\
\hline & female & 7.2 & 8.1 & 9.2 \\
\hline & overall & 10.6 & 11.5 & 10.4 \\
\hline \multirow{3}{*}{$\begin{array}{l}\text { The control of the dean's office and the } \\
\text { department of physical education }\end{array}$} & male & 24.5 & 6.3 & 6.8 \\
\hline & female & 21.6 & 20.2 & 7.7 \\
\hline & overall & 22.6 & 15.5 & 7.2 \\
\hline \multirow{3}{*}{ Parents } & male & 7.5 & 3.1 & 3.4 \\
\hline & female & 2.1 & 2.0 & 6.2 \\
\hline & overall & 4.0 & 2.4 & 4.8 \\
\hline
\end{tabular}


Table VII. The students' confidence in improving health through physical exercises and sport $(n=647, \%)$

\begin{tabular}{|c|c|c|c|c|}
\hline \multirow{2}{*}{ Factors } & \multirow{2}{*}{ Gender } & \multicolumn{2}{|c|}{ Years of study } & \multirow{2}{*}{$\begin{array}{c}\text { Total } \\
\%\end{array}$} \\
\hline & & $1 \mathrm{st}$ & 2nd & \\
\hline \multirow{3}{*}{$\begin{array}{l}\text { Confident } \\
\text { (positive) }\end{array}$} & male & 71,4 & 82,8 & 76,9 \\
\hline & female & 57,3 & 70,7 & 65,5 \\
\hline & overall & 65,2 & 73,7 & 69,7 \\
\hline \multirow{3}{*}{$\begin{array}{l}\text { Partially confident } \\
\text { (positive) }\end{array}$} & male & 24,8 & 15,6 & 20,6 \\
\hline & female & 41,5 & 24,6 & 30,6 \\
\hline & overall & 32,1 & 22,4 & 26,9 \\
\hline \multirow{3}{*}{$\begin{array}{l}\text { Unconfident } \\
\text { (negative) }\end{array}$} & male & 3,8 & 1,6 & 2,5 \\
\hline & female & 1,2 & 4,7 & 3,9 \\
\hline & overall & 2,7 & 3,9 & 3,4 \\
\hline
\end{tabular}

Table VIII. The confidence of the students of different educational departments in improving health through physical exercise and sport ( $\mathrm{n}=647, \%)$

\begin{tabular}{|c|c|c|c|c|}
\hline \multirow{2}{*}{ Factors } & \multirow{2}{*}{ Gender } & \multicolumn{3}{|c|}{ Education departments } \\
\hline & & special & main & sports \\
\hline \multirow{3}{*}{$\begin{array}{l}\text { Confident } \\
\text { (positive) }\end{array}$} & male & 64.2 & 77.8 & 86.4 \\
\hline & female & 56.7 & 68.4 & 67.6 \\
\hline & overall & 59.4 & 71.7 & 76.7 \\
\hline \multirow{3}{*}{$\begin{array}{l}\text { Partially confident } \\
\text { (positive) }\end{array}$} & male & 35.8 & 19.0 & 10.2 \\
\hline & female & 38.1 & 28.8 & 26.2 \\
\hline & overall & 37.3 & 25.4 & 18.5 \\
\hline \multirow{3}{*}{$\begin{array}{l}\text { Unconfident } \\
\text { (negative) }\end{array}$} & male & - & 3.2 & 3.4 \\
\hline & female & 5.2 & 2.8 & 6.2 \\
\hline & overall & 3.3 & 2.9 & 4.8 \\
\hline
\end{tabular}

Table IX. Conducting independent extracurricular physical exercises by students ( $n=647, \%)$

\begin{tabular}{|c|c|c|c|c|}
\hline \multirow{2}{*}{ Factors } & \multirow{2}{*}{ Gender } & \multicolumn{2}{|c|}{ Years of study } & \multirow{2}{*}{$\begin{array}{c}\text { Total } \\
\%\end{array}$} \\
\hline & & 1 st & 2nd & \\
\hline \multirow{3}{*}{ 1-2 times a week } & male & 30.5 & 31.3 & 31.1 \\
\hline & female & 32.9 & 39.8 & 35.9 \\
\hline & overall & 31.6 & 37.6 & 34.2 \\
\hline \multirow{3}{*}{ 2-3 times a week } & male & 24.8 & 18.8 & 18.9 \\
\hline & female & 15.9 & 17.8 & 15.6 \\
\hline & overall & 20.9 & 18.0 & 16.8 \\
\hline \multirow{3}{*}{4 and more times a week } & male & 11.4 & 21.8 & 15.1 \\
\hline & female & 7.3 & 8.9 & 8.1 \\
\hline & overall & 9.6 & 12.2 & 10.7 \\
\hline \multirow{3}{*}{ Not once } & male & 33.3 & 28.1 & 34.9 \\
\hline & female & 43.9 & 33.5 & 40.4 \\
\hline & overall & 37.9 & 32.2 & 38.3 \\
\hline
\end{tabular}

Note. Independent classes include performing morning gymnastics, various sets of physical exercises at home, special walks, dosed walking, healthimproving run, walking holidays, training in clubs, gyms, etc.

of the contingent in many cases (according to self-assessment data, a significant number of students corresponded to the health level of people aged 25-35 years and more). The data obtained indicated that the health state of a large number of students did not correspond to their age characteristics.

\section{DISCUSSION}

The health state of the students of higher educational institutions is determined by the interaction of a large number of factors - social and biological, material and spiritual that are difficult and contradictory to interact with one another. Physical education should undoubtedly be related to the factors of health preservation. However, different types of physical culture activities (fitness and health education, sports, physical recreation, motor rehabilitation, etc.) do not automatically guarantee good health. Numerous scientific researches, recommendations of state bodies and industry experts, who were engaged in the improvement of physical education at HEI of Ukraine, did not make radical changes in the health state of students. Physical culture and 
health-improving activities at modern HEI of Ukraine are not able to provide the basis of professional health, longevity and physical capacity of future specialists $[31,32]$.

To improve the health of students, it is necessary to reveal the connection of health with the environment, to determine the lifestyle, the attitude of students to their own health, etc. As all students have different levels of health and the optimal range of physical exercises, increasing this level, any average physical activity during group classes can stabilize, increase or decrease the level of health. Therefore, in order to determine the most effective amount of physical activity for the students with different levels of health, first, it is necessary to define the structure of the health level, to identify its components, the nature of their relationship with physical activity. Existing health-assessment methods do not sufficiently consider these features. To carry out the efficient correction and management of the process of physical education, the way of loads determination and individual tasks application should be fairly simple, the accessible methods of students ' health assessment, which do not require mathematical processing of the data obtained, long surveys and which are clear for both teachers and students. One of these ways is self-assessment of the health by students. It should be considered that the close connection between the organism's resiliency and the subjective emotional state of a person transforms resiliency into a sense of health. The state of the internal environment and the subjective organism perception by a person can serve as a basis for assessing their health $[33,34,35]$. Therefore, for students' self-assessment of a health state, we developed criteria that they were required to evaluate using a simplified 5-point system: 1) the level of physical development, performance, and fitness; 2) the absence of hereditary, chronic and other diseases; 3 ) the absence of headaches, pain in joints, back, internal organs; 4) the work of analyzers (sense of hearing, vision, etc.); 5) appetite, sleep, mood, well-being, the pleasure of life; 6) the absence of diseases indicated after doctor's examination. The students with a grade point average of 5 were indicated to have a perfect health state, 5-4 - a good health state, 4-3 - satisfactory, 3-2 - poor, and 2-1 - very poor. The indicators obtained through the original five-scale method of V. P. Voytenko showed a significant correlation $(r=-0.427 ; \mathrm{p}<0.05)$. It revealed that the proposed methodology can give a reliable assessment of the students' health. To make this method faster and easier to use, we outlined the characteristics of health conditions, which allows a student to define a certain state of health easily after studying them.

The perfect health status of students is characterized by high rates of physical development, the absence of any defects (normal height, correspondence of body weight to height, proportionally-developed muscles, correct posture, etc.), high physical performance, mainly excellent and good physical fitness, the absence of chronic diseases, symptoms of hereditary diseases, headaches, pain in joints, back, internal organs, etc. The students with perfect health have good eyesight, hearing, memory, appetite, sleep, they are cheerful, happy with their lives, sociable and do not have unpleasant feelings. The doctors do not find deviations from the norm during an examination.

The good health status of students is not much different from the perfect. Basically, it is a slight difference in the indicators of physical development (some deviations of body weight and morphological status, which do not significantly affect the motor activity), performance, physical fitness (the indicators are mostly good, tending to excellent). They also do not have constitution defects, chronic diseases, the effects of traumas and illnesses, headaches, pain in joints, back, internal organs, etc. They are characterized by good appetite, sleep, cheerfulness. The doctors do not find significant health abnormalities during an examination.

The satisfactory health status is characteristic of students who have good and moderate levels of physical development, performance, and fitness. Some students are overweight, have slight defects in posture, disproportionate development of the muscular system. They are characterized by impaired motor activity, sometimes have symptoms of fatigue. The headaches, pain in joints, organs, back happen rarely. They do not have any particular illnesses or disorders; they have a good appetite and sleep. Their psychological condition is normal. The doctors can detect some minor deviations from the norm during an examination.

The students with poor health status are characterized by poor physical development (disproportionate weight and height, overweight or underweight, poorly and disproportionately developed muscular system, etc.), poor performance and physical fitness (satisfactory and poor indicators). They may have chronic diseases, congenital anomalies, are more likely to suffer from a disability. Such people have headaches, pain in, back, joints, and internal organs more often. They may have impaired vision, hearing, coordination of movements, and health problems. Their motor activity is low. The appetite, sleep, and psychological state are normal. Such students do not always feel comfortable and are less cheerful.

The students with very poor health status are characterized by poor physical development (physique and posture disorders, disproportionate development of the muscular system, etc.), very poor physical and mental performance, and mostly bad physical fitness. They have chronic and hereditary diseases, pains, life discomfort more often than others. The motor activity is very poor and physical activity is mostly absent. They have significant health disabilities, which are often accompanied by the loss of labor capacity.

\section{CONCLUSIONS}

1. All the factors that affect the students' health can have both positive and negative effects. The factors that do not contribute to health improvement include violation of the regime of work and rest, ignoring physical exercises, irregular eating, overeating, shortening the duration of night sleep, smoking, drinking, etc. At the same time, a wide range of specific components of the educational process and a healthy lifestyle of students can have dif- 
Table X. The factors encouraging independent extracurricular physical exercises and sport ( $n=647, \%)$

\begin{tabular}{|c|c|c|c|c|}
\hline \multirow{2}{*}{ Factors } & \multirow{2}{*}{ Gender } & \multicolumn{2}{|c|}{ Years of study } & \multirow{2}{*}{$\begin{array}{c}\text { Total } \\
\%\end{array}$} \\
\hline & & $1 \mathrm{st}$ & 2nd & \\
\hline \multirow{3}{*}{ The desire to improve health } & male & 49.5 & 57.8 & 53.4 \\
\hline & female & 45.1 & 63.9 & 57.7 \\
\hline & overall & 47.6 & 62.4 & 56.1 \\
\hline \multirow{3}{*}{ The desire to be attractive } & male & 21.9 & 26.6 & 24.4 \\
\hline & female & 35.4 & 41.9 & 43.5 \\
\hline & overall & 27.8 & 38.0 & 36.5 \\
\hline \multirow{3}{*}{ Taking pleasure in physical exercises } & male & 26.7 & 42.2 & 32.4 \\
\hline & female & 11.0 & 25.7 & 21.3 \\
\hline & overall & 19.8 & 29.8 & 25.3 \\
\hline \multirow{3}{*}{ Physical education teacher } & male & 23.8 & 12.5 & 18.9 \\
\hline & female & 29.3 & 20.9 & 23.0 \\
\hline & overall & 26.2 & 18.8 & 21.5 \\
\hline \multirow{3}{*}{ Harmony of spiritual and physical development } & male & 12.4 & 23.4 & 20.2 \\
\hline & female & 23.2 & 20.9 & 20.0 \\
\hline & overall & 17.1 & 21.6 & 20.1 \\
\hline \multirow{3}{*}{ The desire to improve the athletic performance } & male & 21.9 & 37.5 & 26.9 \\
\hline & female & 11.0 & 18.8 & 15.6 \\
\hline & overall & 17.1 & 23.5 & 19.8 \\
\hline \multirow{3}{*}{ Friends } & male & 27.6 & 21.9 & 26.9 \\
\hline & female & 20.7 & 17.8 & 15.2 \\
\hline & overall & 24.6 & 18.8 & 19.5 \\
\hline \multirow{3}{*}{ Radio, TV, press, books } & male & 8.6 & 15.6 & 13.0 \\
\hline & female & 18.3 & 13.1 & 15.2 \\
\hline & overall & 12.8 & 13.7 & 14.4 \\
\hline \multirow{3}{*}{ The availability and accessibility of sports facilities } & male & 18.1 & 12.5 & 15.1 \\
\hline & female & 13.4 & 9.4 & 11.5 \\
\hline & overall & 16.0 & 10.2 & 12.8 \\
\hline \multirow{3}{*}{ Parents } & male & 6.7 & 4.7 & 7.6 \\
\hline & female & 6.1 & 7.3 & 7.3 \\
\hline & overall & 6.4 & 6.7 & 7.4 \\
\hline \multirow{3}{*}{ An example of a famous athlete } & male & 10.5 & 14.1 & 10.9 \\
\hline & female & 6.1 & 3.7 & 5.1 \\
\hline & overall & 8.6 & 6.3 & 7.3 \\
\hline \multirow{3}{*}{ The knowledge and skills in motor activity, received at HEI } & male & 6.7 & 6.3 & 5.0 \\
\hline & female & 11.0 & 7.9 & 8.3 \\
\hline & overall & 8.6 & 7.5 & 7.1 \\
\hline \multirow{3}{*}{ The need to communicate with others } & male & 4.8 & 12.5 & 8.0 \\
\hline & female & 8.5 & 6.3 & 5.9 \\
\hline & overall & 6.4 & 7.8 & 6.6 \\
\hline \multirow{3}{*}{ The advice of friends } & male & 3.8 & 15.6 & 8.0 \\
\hline & female & 7.3 & 5.2 & 4.9 \\
\hline & overall & 5.3 & 7.8 & 6.0 \\
\hline \multirow{3}{*}{ Major sporting events (Olympics, championships) } & male & 7.6 & 10.9 & 9.2 \\
\hline & female & 2.4 & 3.1 & 3.4 \\
\hline & overall & 5.3 & 5.1 & 5.6 \\
\hline & male & 8.6 & 4.7 & 7.1 \\
\hline Career & female & 3.7 & 3.1 & 3.9 \\
\hline & overall & 6.4 & 3.5 & 5.1 \\
\hline & male & 1.9 & - & 3.4 \\
\hline A high level of one's own or parents' well-being & female & 1.2 & 2.1 & 2.0 \\
\hline & overall & 1.6 & 1.6 & 2.5 \\
\hline & male & 6.7 & 1.6 & 3.4 \\
\hline An example of statesmen and politicians & female & - & - & 1.0 \\
\hline & overall & 3.7 & 0.4 & 1.9 \\
\hline
\end{tabular}


Table XI. The health self-assessment by the students of different years ( $n=647, \%)$

\begin{tabular}{|c|c|c|c|c|c|}
\hline \multirow{2}{*}{ The level of health } & \multirow{2}{*}{ Gender } & \multicolumn{4}{|c|}{ Years of study } \\
\hline & & $1 \mathrm{st}$ & 2nd & $3 r d$ & 4th \\
\hline \multirow{2}{*}{ Perfect } & male & 1.9 & 3.1 & 2.9 & 2.9 \\
\hline & female & 2.4 & 3.7 & 2.0 & 4.7 \\
\hline \multirow{2}{*}{ Good } & male & 18.1 & 21.9 & 17.1 & 20.6 \\
\hline & female & 18.3 & 14.7 & 17.7 & 19.9 \\
\hline \multirow{2}{*}{ Satisfactory } & male & 44.8 & 45.3 & 48.6 & 50.0 \\
\hline & female & 54.9 & 51.3 & 54.9 & 52.9 \\
\hline \multirow{2}{*}{ Poor } & male & 29.5 & 23.4 & 28.5 & 20.6 \\
\hline & female & 19.5 & 24.5 & 19.6 & 17.8 \\
\hline \multirow{2}{*}{ Very poor } & male & 5.7 & 6.3 & 2.9 & 5.9 \\
\hline & female & 4.9 & 5.8 & 5.8 & 4.7 \\
\hline
\end{tabular}

Table XII. The health self-assessment by the students of different educational departments ( $\mathrm{n}=647, \%)$

\begin{tabular}{|c|c|c|c|c|}
\hline \multirow{2}{*}{ The level of health } & \multirow{2}{*}{ Gender } & \multicolumn{3}{|c|}{ Education departments } \\
\hline & & special & main & sports \\
\hline \multirow{2}{*}{ Perfect } & males & - & 4.8 & 32.2 \\
\hline & females & - & 2.7 & 20.1 \\
\hline \multirow{2}{*}{ Good } & males & 1.9 & 19.1 & 49.2 \\
\hline & females & 2.1 & 21.5 & 32.1 \\
\hline \multirow{2}{*}{ Satisfactory } & males & 22.6 & 64.2 & 18.6 \\
\hline & females & 28.9 & 63.5 & 46.2 \\
\hline \multirow{2}{*}{ Poor } & males & 54.7 & 8.7 & - \\
\hline & females & 50.5 & 7.8 & 1.6 \\
\hline \multirow{2}{*}{ Very poor } & males & 20.8 & 3.2 & - \\
\hline & females & 18.5 & 4.5 & - \\
\hline
\end{tabular}

ferent effects on life. The students' lifestyle that includes physical exercises is of particular importance.

2. The students' self-assessment of a health state is an indicator of their objective state at the affective and cognitive levels of their mental activity, which reflects the set of sensations at the physiological and psychophysiological levels, features of the biochemical, hormonal and nervous state. The indicators of the students' self-assessment of a health state are subjective, may depend on the psychological characteristics of an individual, well-being at the time of the survey, health status, diseases, medical examination results, environmental status, etc. The self-assessment of a health state by students is the fastest and most effective method of determining the amount of physical activity for students with different levels of health.

The self-assessment indicated that there was no significant difference in the health state between the students of different years of study but there was a difference between males and females. The analysis of the results of health self-assessment by the students from different educational departments indicates significant differences between the educational departments: there were no students with perfect health in the special department but the number of the students with a perfect health state accounted for 4.8
$\%$ of males and $2.7 \%$ of females in the main educational department, and $32.2 \%$ of males and $20.1 \%$ of females in the sports department.

3. The development of educational, health-preserving technologies in the physical education of students requires an efficient assessment of their own health by each student in order to consciously engage them in active motor activity. The introduction of modern innovative technologies that will provide high performance and health preservation into the life of student youth requires some knowledge and high-quality assessment of their health status. The analysis of our own researches and literary sources gives grounds to state that there is a clear tendency of health deterioration of students, who have different health states, and the level of disease incidence of students of one and the same region is different. The proposed self-assessment of a health state by students lets to manage the process of physical education efficiently, to determine the amount of physical activity and to apply individual tasks. At the same time, the introduction of the self-assessment of students' health requires educational and explanatory work on 1) the concept of health and its components; 2) the methods of determining the physical condition and assessment of one's own health; 3 ) training and acquisition of skills and abilities to manage 
one's own health; 4) identifying and following the most important priorities of a healthy lifestyle as the factors of formation, preservation, strengthening, and recovery of health.

The prospects for further research are aimed at checking the efficiency of the original method of students' self-assessment of their health in the process of physical education at higher educational institutions of Ukraine.

\section{REFERENCES}

1. Kharchenko 0., Kharchenko N., Shaparenko I., Sakharova L., Yushchenko, Yu. Analysis of the physical development of youth and the state of its health. Wiad Lek. 2019; 72(4): 575-578.

2. Warburton D., Nicol C. W., Bredin S. S. D. Health benefits of physical activity: the evidence. Canadian Medical Association Journal. 2006; 174: 801-809.

3. Prontenko K., Griban G., Dovgan N. et al. Students' health and its interrelation with physical fitness level. Sport Mont. 2019; 17(3): 41-46. doi 10.26773/smj.191018.

4. Bulych E. Gh., Muravov Y. V. Zdorovje cheloveka: Byologhycheskaja osnova zhyznedejateljnosty y dvyghateljnaja aktyvnostj v ee stymuljacyy [Human health: the biological basis of vital activity and motor activity in its stimulation]. Kyiv: Olympic Literature; 2002, 424 p. (In Russian).

5. Kosiba G., Gacek M., Wojtowicz A., Majer M. Level of knowledge regarding health as well as health education and pro-health behaviours among students of physical education and other teaching specializations. Baltic Journal of Health and Physical Activity. 2019; 11(1): 83-95. doi: 10.29359/BJHPA.11.1.09

6. Muntjan V. S. Analyz faktorov, opredeljajushhykh zdorovj'e cheloveka y okazyvajushhykh na negho vlyjanyja [Analysis of factors that determine human health and influence it]. Fyzycheskoe vospytanye studentov. 2010; 6: 44-47. (In Russian).

7. Gruzieva T., Galiienko L., Pelo I. et al. Health and lifestyle of students' youth: status, problems and ways of solution. Wiad Lek. 2018; 71(9): 1753-1758.

8. Maglovanyi A. V. Osnovy informacijnogho polja zdorov'ja osobystosti [Basics of information field of personality health]. Visnyk Chernighivsjkogho nacionaljnogho pedaghoghichnogho universytetu imeni T. Gh. Shevchenka. Serija: Pedaghoghichni nauky. Fizychne vykhovannja ta sport. 2010; 81: 285-289. (In Ukrainian).

9. Apanasenko G. L. Knygha o zdorovj'e [Health Book]. Kyev: Medknygha; 2007, 132 p. (In Russian).

10. Paffenbarger R. S., Olsen E. Zdorovyiy obraz zhizni [Healthy lifestyle]. Kyiv: Olympic Literature; 1999, 320 p. (In Russian).

11. World Health Organization (2015). Global recommendations on physical activity for health. Available from: http://www.who.int/ dietphysicalactivity/factsheet_recommendations.

12. Vilenskiy M. Ya. Sotsialno-psihologicheskie determinantyi formirovaniya zdorovogo obraza zhizni [Socio-psychological determinants of a healthy lifestyle]. Teoriya i praktika fizicheskoy kulturyi. 1994; 9: 9-11. (In Russian).

13. Gninyuk 0. Pedagogichniy kontrol za stanom zdorov'ya u sistemi fizichnogo vihovannya maybutnih inzheneriv informatsiynokomunikatsiynogo fahu [Pedagogical control of health state in the system of physical education of future engineers of information and communication profession]. Flzichna kultura, sport ta zdorov'ya natsiyi. 2006; 312-316. (In Ukrainian).
14. Malimon 0., Volchinskiy A. Dinamika zahvoryuvanosti ta stanu zdorov'ya studentiv [Dynamics of student morbidity and health]. Fizichne vihovannya, sport i kultura zdorov'ya u suchasnomu suspilstvi. 2005; 1: 286-289. (In Ukrainian).

15. Bolotin A., Bakayev V. Structure and content of the educational technology of managing students' healthy lifestyle. Journal of Physical Education and Sport. 2015; 15(3): 362-364. doi:10.7752/ jpes.2015.03054.

16. Budagh'janc Gh. M. Zdorovyj sposib zhyttja - osnovna umova profilaktyky deviantnoji povedinky pidlitka (istorychnyj aspekt) [Healthy lifestyle - the main condition for the prevention of adolescent deviant behavior (historical aspect)]. Pedaghoghika, psykhologhija ta medykobiologhichni problemy fizychnogho vykhovannja i sportu. 2010; 6: 25-28. (In Ukrainian).

17. Duboghaj 0. D., Aljoshyna A. I., Lavrynjuk V. Je. Osnovni ponjattja i terminy zdorov'jazberezhennja ta fizychnoji reabilitaciji v systemi osvity [Basic concepts and terms of healthcare and physical rehabilitation in the education system]. Lucjk:Volynsjkyj nacionaljnyj universytet imeni Lesi Ukrajinky; 2011, 296 p. (In Ukrainian).

18. Mozolev 0., Bloshchynsky I., Alieksieiev 0. et al. Influence of modern fitness technologies on the state of health and development of motor abilities of 17-19-year-old female students. Journal of Physical Education and Sport. 2019; 19(Supplement issue 3): 917-924. doi:10.7752/jpes.2019.s3132.

19. Griban G. P. Zhyttiediialnist ta rukhova aktyvnist studentiv [Life activity and mobility of students]. Zhytomyr: Ruta; 2009, 594 p. (In Ukrainian).

20. Prontenko K., Bloshchynskyi I., Griban, G. et al. Formation of readiness of future physical culture teachers for professional activity. Universal Journal of Educational Research. 2019; 7(9): 1860-1868. doi: 10.13189/ ujer.2019.070903.

21. Griban G., Prontenko K., Zhamardiy V. et al. Professional stages of a physical education teacher as determined using fitness technologies. Journal of Physical Education and Sport. 2018; 18(2): 565-569. doi:10.7752/jpes.2018.02082.

22. Ghoncharenko M. S., Novykova V. Je. Valeologhichni aspekty formuvannja zdorov'ja u suchasnomu osvitjansjkomu procesi [Valeology aspects of the formation of health in the modern educational process]. Pedaghoghika, psykhologhija ta metodyko-biologhichni problemy fizychnogho vykhovannja i sportu. 2010; 6:45-51. (In Ukrainian).

23. Vayner E. N. Valeologiya [Valeology]. Moskow: «Flinta», «Nauka»; 2001, 416 p. (In Russian).

24. Prontenko K., Griban G., Aloshyna A. et al. The physical development and functional state as the important components of the students' health. Wiad. Lek. 2019; 72 (12a): 2348-2353. doi: 10.36740/WLek201912115.

25. Griban G., Tymoshenko 0., Arefiev V. et al. (2020). The role of physical education in improving the health status of students of special medical groups. Wiad. Lek. 2020; 73 (3): 534-540. doi: 10.36740/ WLek202003125.

26. Voytenko V. P. Zdorove zdorovyih [Healthy health]. - Kyiv: Zdorov'ya; 1991, 248 p. (In Russian).

27. Semeniv B., Babych A., Bilenjkyj P. et al. Educational model of physical training of students of bio-technological profiles. Physical Education, Sports and Health Culture in Modern Society, 2018; 1(41): 52-60. doi:https://doi.org/10.29038/2220-7481-2018-01-52-60.

28. Zavydivska 0., Zavydivska N., Khanikiants 0 . Self-management as a condition for creating a health culture among students. Journal of Physical Education and Sport. 2016; 16(1): 592-597. doi:10.7752/ jpes.2016.s1093. 
29. Futornyj S. M. Dvyghateljnaja aktyvnostj y ee vlyjanye na zdorovj'e y prodolzhyteljnostj zhyzny cheloveka [Motor activity and its effect on human health and longevity]. Fyzycheskoe vospytanye studentov. 2011; 4: 79-84. (In Russian).

30. Prontenko K., Griban G., Bloshchynskyi I. et al. Improvement of students' morpho-functional development and health in the process of sport-oriented physical education. Wiad Lek. 2020; 73(1): 1753-1758. doi: 10.36740/WLek202001131.

31. Leuciuc F. Perception on physical education among students. Revista Romaneasca pentru Educatie Multidimensionala. 2018; 10(2): 134-143. doi:https://doi.org/10.18662/rrem/51.

32. Apanasenko G., Dolzhenko L. Rivenj zdorov'ja i fiziologhichni rezervy orghanizmu. [The level of health and physiological reserves of the organism]. Teorija i metodyka fizychnogho vykhovannja i sportu. 2007; 1: 17-21. (In Ukrainian).

33. Dolzhenko L. Fizichna pidgotovlenist studentiv z riznim rivnem somatichnogo zdorov'ya [Physical fitness of students with different levels of somatic health]. Moloda sportivna nauka Ukrayini. 2010; 9(4): 139-143. (In Ukrainian).

34. Makarov S., Stoyan N., Serheta I., Taran 0., Dyakova 0. Peculiarities of the interaction of the indicators of psychophysiological adaptation of modern students in the context of the effective monitoring of individual health of young women and young men. Wiad. Lek. 2019; 72 (5a): 1053-1058.

35. Krutsevych T.Yu. Teoriia i metodyka fizychnoho vykhovannia [Theory and methods of physical education]: pidruchnyk dlia stud. vuziv fiz. vykhov. isportu. T. 1. Zahalni osnovy teorii i metodyky fizychnoho vykhovannia. Kyiv: Olympic Literature; 2008, 391 p. (In Ukrainian).
The work was carried out according to the plan of the research work of Zhytomyr Ivan Franko State University and University for 2014-2024 on the theme of "Theoretical and methodological bases of improving the educational process of physical education at higher educational institutions" (state registration number 0114U003978).

\section{ORCID and contibutionship:}

Grygoriy P. Griban: 0000-0002-9049-1485 A,B,F

Zoia M. Dikhtiarenko: 0000-0003-1869-7494 ${ }^{B, C}$

Eduard A. Yeromenko: 0000-0002-8029-2247 ${ }^{B, F}$

Andrii M. Lytvynenko: 0000-0002-0352-9511 C,E

Alla A. Koval: 0000-0002-8444-4738 ${ }^{B, E}$

Irina V. Ramsey: 0000-0002-6964-7203 D,F

Vadym O. Muzhychok: 0000-0001-9429-6890 C,E

\section{Conflict of interest:}

The Authors declare no conflict of interest.

\section{CORRESPONDING AUTHOR Grygoriy P. Griban}

Zhytomyr Ivan Franko State University

Zhytomyr, Ukraine

tel: +380675069142

e-mail: prontenko-kostya@ukr.net

Received: 11.03 .2020

Accepted: 01.07.2020

A - Work concept and design, B - Data collection and analysis, C - Responsibility for statistical analysis,

$\mathbf{D}$-Writing the article, $\mathbf{E}$-Critical review, $\mathbf{F}$ - Final approval of the article 